\title{
PENGARUH PENGETAHUAN KEUANGAN, SIKAP KEUANGAN, DAN LOCUS OF CONTROL TERHADAP PERILAKU KEUANGAN MAHASISWA PRODI MANAJEMEN UNIVERSITAS MUHAMMADIYAH GRESIK
}

\author{
Safira Cahyani Ula Muhidia \\ Program Studi Manajemen Fakultas Ekonomi dan Bisnis \\ Universitas Muhammadiyah Gresik
}

\begin{abstract}
This study aims to test the Influence of Financial Knowledge, Financial Attitudes, and Locus Of Control Against Student Financial Behavior Management Study University of Muhammadiyah Gresik. The object of this research is the students of S1 Study Program of Muhammadiyah University Gresik. A total of 191 respondents were selected based on the proportionate stratified random sampling method. Hypothesis testing is done by using multiple linear regression analysis with SPSS program 19. The results showed that the financial knowledge variable has no effect on financial behavior. While the financial attitude and locus of control have a significant positive effect on financial behavior.
\end{abstract}

Keywords: Financial Knowledge, Financial Attitude, Locus Of Control, Financial Behavior.

\section{PENDAHULUAN}

Perilaku keuangan saat ini telah menjadi isu yang cukup banyak diperbincangkan. Perilaku keuangan berkaitan dengan perilaku konsumtif yang banyak dimiliki oleh masyarakat. Hal ini cenderung menyebabkan perilaku keuangan yang tidak bertanggungjawab karena masih kurangnya pengetahuan keuangan, sikap dalam menabung, berinvestasi dan lainnya yang berkaitan dengan keuangan.

Perilaku mahasiswa dalam mengeluarkan uang tergantung dari pengetahuan keuangan yang didapatkan. Pengetahuan keuangan sangat diperlukan dalam mengelola keuangan untuk kebutuhan hidup masing-masing individu. Penyebab terbesar dari penentuan keuangan yang buruk didasarkan dari pengetahuan keuangan yang minim atau kurang.
Permasalahan utama dari mahasiswa Manajemen UMG dalam mengendalikan keuangan karena banyak yang tidak tinggal dengan orang tuanya. Memiliki pengetahuan keuangan dengan baik belum tentu dapat membuktikan bahwa pengetahuan tersebut menjadi suatu jaminan untuk menentukan keuangan.

Permasalahan lain yang dihadapi adalah banyaknya mahasiswa Manajemen yang beralasan tidak bisa secara bijaksana dan bertanggung jawab dalam mengelola keuangannya. Mahasiswa Manajemen UMG juga masih banyak yang memiliki perilaku konsumtif dalam mengelola keuangannya. Mereka lebih memilih mementingkan keinginan dan hasratnya daripada kebutuhannya. Aryani (2006) menyatakan masyarakat dalam kehidupan modern telah banyak yang kehilangan hubungan dalam mengkonsmusi sesuatu. Perilaku 
konsumtif mendorong masyarakat untuk mengkonsumsi barang atau jasa berlebihan tanpa memperhatikan skala prioritasnya.

Mahasiswa manajemen biasa mengkonsumsi barang yang tidak dibutuhkan masih menjadi suatu hal yang sering terjadi. Sikap keuangan sangat mempengaruhi kebiasaan hidupnya, seperti yang tinggal di lingkungan keluarga yang tinggi akan lebih memikirkan bahwa seseorang bisa mendapatkan apapun yang diinginkan tanpa menerapkan sikap keuangan yang baik.

Banyak penelitian terdahulu yang menyatakan bahwa terdapat pengaruh positif antara pengetahuan keuangan, sikap keuangan, dan locus of control terhadap perilaku keuangan Mahasiswa. Sehubungan dengan latar belakang yang ada, maka peneliti tertarik untuk mengangkat tema yang berjudul "Pengaruh Pengetahuan Keuangan, Sikap Keuangan, dan Locus Of Contol Terhadap Perilaku Keuangan Mahasiswa Prodi Manajemen Universitas Muhammadiya Gresik".

\section{TINJAUAN PUSTAKA}

Peneliti terdahulu yang dilakukan oleh Kurnia Listiani (2017) yang berjudul Pengaruh Financial Knowledge, Locus Of Control, dan Financial Attitude Terhadap Financial Management Behavior Pada Mahasiswa. Hasil analisis menyatakan bahwa financial knowledge berpengaruh negatif terhadap financial management behavior, sedangkan financial attitude dan locus of control berpengaruh positif terhadap financial management behavior.

Peneliti terdahulu yang lainnya dilakukan oleh Herdjiono dan Damanik (2016) yang berjudul Pengaruh Financial Attitude,
Financial Knowledge, Parental Income Terhadap Financial Management Behavior. Hasil analisis menyatakan bahwa financial attitude memiliki pengaruh terhadap financial management behavior, sedangkan parental income dan financial knowledge tidak berpengaruh terhadap financial management behavior.

\section{Perilaku Keuangan}

Perilaku keuangan ini muncul pada tahun 1990-an yang sejalan dengan perkembangan bisnis dan akademik. Menurut Ricciardi (2017:13) mengemukakan bahwa perilaku keuangan adalah suatu disiplin ilmu yang mempunyai berbagai interaksi tentang disiplin ilmu dan akan terus menerus beritegrasi. Pendapat lain dikemukakan oleh Gitman (2017:14), perilaku keuangan merupakan cara seorang individu dalam mengambil keputusan untuk mengelola sumber dananya (uang). Sementara Hilgert et al. dalam Anis (2015:103) mengatakan bahwa perilaku keuangan berkaitan dengan cara seseorang untuk dapat mengelola dan menggunakan sumber daya keuangan yang dimiliki.

\section{Pengetahuan Keuangan}

Pada dasarnya setiap orang harus memiliki pengetahuan keuangan untuk dapat menentukan bagaimana perilaku keuangannya. Pengetahuan keuangan menurut Aminatuzzahra' (2014:12) mengemukakan bahwa jika ingin memiliki pengetahuan keuangan yang baik, maka seseorang harus mempunyai kemampuan keuangan dan mencoba belajar untuk menggunakan alat keuangan (ATM, kartu kredit, cek, uang tunai, dan lainlain). Dengan alat keuangan ini, seseorang dapat mengembangkan perilakunya dalam mengambil keputusan pada keuangannya. 
Cude, Lawrence, Lyons, Metzger, LeJeune, Marks, dan Machtmes (2006:12), menyatakan bahwa pengetahuan sangat diperlukan dalam mengelola keuangan. Hal ini nantinya akan membuat seseorang dapat berpikir untuk mencoba berinvestasi dan tidak lagi dengan mudah mengabaikan hal tersebut seperti waktu yang sebelumnya. Indikator yang digunakan oleh Chen dan Volpe (2016:232), pemahaman yang berkaitan dengan pengetahuan dasar keuangan yaitu pengetahuan umum keuangan, tabungan dan pinjaman, asuransi dan investasi.

\section{Sikap Keuangan}

Dalam keseharian setiap orang pasti memiliki sikap dalam hidupnya. Sikap tersebut diperlukan dalam setiap kehidupan seseorang dimana sebagian besar orang akan mengekspresikan perasaan mereka. Sikap merupakan suatu cara seseorang dalam bereaksi terhadap suatu rangsangan yang akan timbul dari seseorang atau situasi.

Sikap keuangan yang dimiliki setiap individu akan membantu individu untuk mengerti bagaimana sikap dan perilaku yang dimiliki dalam keputusan keuangannya. Menurut Pankow (dikutip dalam Zahroh, 2014: 13), menyatakan bahwa sikap keuangan adalah suatu keadaan yang ada dalam pikiran, pendapat, dan suatu penilaian yang menyangkut dalam hal keuangan.

Menurut Listiani (2017:7) menyebutkan beberapa indikator yaitu: menabung secara teratur dan rutin, menulis tujuan atau target keuangan, melakukan penulisan rencana anggaran, bertanggung jawab atas dirinya sendiri, hemat terhadap uang, dan perencanaan keuangan.

\section{Locus of Control}

Konsep tentang Locus of control pertama kali dikemukakan oleh Rotter dalam buku Howard S. Friedman (2006: 275), seorang ahli teori pembelajaran sosial. Rotter mengemukakan bahwa individu yang memiliki keyakinan yang stabil akan mendapatkan suatu hal penting pada situasi di dalam diri yang akan menentukan perilaku individu tersebut. Elemen utama dari teori yang dikemukakan oleh Rotter merupakan konsep eksternal atau internal dari reinforcement, atau lokus kontrol (Locus of control). Tindakan dari individu akan membuat kemunculan hasil akhir yang diinginkan internal locus of control atau tindakan yang dilakukan individu dari luar seperti kemampuan atau kekuatan pada hasil akhir yang diinginkan tersebut akan terjadi eksternal locus of control.

Menurut Kreitner dan Kinicki (2013:15), mengemukakan locus of control adalah keyakinan seorang individu yang dapat mempengaruhi setiap kejadian yang terjadi didalam hidupnya. Locus of control dioperasikan sebagai konstruk internal dan eksternal yang mengukur keyakinan seseorang atas kejadian yang menimpa kehidupannya.

Menurut konsep yang dikemukakan oleh Rotter mengenai locus of control, terdapat dua tipe locus of control, yaitu locus of control internal dan locus of control eksternal. Menurut Crider (Ghufron \& Risnawati 2010:23-24) perbedaan karakteristik dari dua tipe tersebut, yaitu:

1. Locus Of Control Internal
a. Pekerja keras
b. Mempunyai inisiatif atau kreatifitas yang tinggi.
c. Selalu berusaha untuk dapat memecahkan permasalahan.
d. Berpikir ekfektif. 
e. Selalu punya persepsi bahwa usaha harus selalu dilakukan jika ingin mendapatkan kesuskesan.

2. Locus Of Control Eksternal

a. Kurang punya inisiatif atau kreatifitas.

b. Mudah menyerah

c. Selalu berpikir jika ada suatu korelasi antara usaha dan kesuksesan.

d. Kurang dalam mencari informasi.

\section{Hubungan Antar Variabel}

Hubungan Pengetahuan Keuangan terhadap Perilaku Keuangan

Menurut Ersha (2016), menyatakan bahwa pengetahuan keuangan berpengaruh positif terhadap perilaku keuangan. Seseorang yang memiliki kekurangan pada pengetahuan keuangannya diakibatkan dari pendidikannya. Pendidikan akan dapat meningkatkan pengetahuan keuangan seseorang yang akan memudahkan dalam pengambilan keputusan. Semakin banyak mengetahui pengetahuan keuangan, maka semakin baik pula seseorang dalam menggunakan uangnya dengan bijak.

\section{Hubungan Sikap Keuangan terhadap Perilaku Keuangan}

Menurut Kurnia (2017), mengatakan bahwa sikap keuangan berpengaruh positif terhadap perilaku keuangannya. Jadi semakin baik sikap keuangannya, maka akan semakin baik pula perilaku seseorang dalam mengelola keuangannya dan membuat seseorang cenderung lebih bijak pada perilaku keuangannya.

\section{Hubungan Locus of Control terhadap Perilaku Keuangan}

Menurut Kurnia (2017), dalam penelitiannya, locus of control berpengaruh positif terhadap perliaku keuangan. Locus of control adalah seseorang yang dapat mengontrol kejadian yang terjadi pada dirinya, baik itu kejadian baik atau buruk. Dengan memiliki locus of control, maka seseorang akan lebih mudah untuk mengontrol dirinya. Locus of control memiliki dua orientasi yaitu locus of control internal dan locus of control eksternal. Locus of control internal ini menilai bagaimana seseorang dapat mengendalikan kejadian yang ada, sedangkan seseorang yang mempunyai locus of control eksternal ini akan cenderung kurang bangga pada dirinya, akan lebih terpengaruh, dan kurang mempunyai harapan pada pengambilan keputusan.

\section{Hipotesis}

Berdasarkan latar belakang dan permasalahan yang ada diarahkan untuk merujuk pada dugaan sementara, yaitu:

1. Diduga Pengetahuan Keuangan berpengaruh signifikan terhadap Perilaku Keuangan Mahasiswa Prodi Manajemen UMG.

2. Diduga Sikap Keuangan berpengaruh signifikan terhadap Perilaku Keuangan Mahasiswa Prodi Manajemen UMG.

3. Diduga Locus Of Control berpengaruh signifikan terhadap Perilaku Keuangan Mahasiswa Prodi Manajemen UMG.

\section{METODOLOGI PENELITIAN}

Penelitian ini menggunakan pendekatan kuantitatif yang bersifat deduktif infransial. Penelitian ini dilakukan pada Mahasiswa Prodi Manajemen di Universitas Muhammadiyah Gresik. Adapun populasi dalam penelitian ini adalah Mahasiswa Prodi Manajemen UMG 
Angkatan tahun 2015 dan 2016 yang telah menempuh mata kuliah akuntansi, dan manajemen keuangan, mahasiswa masih aktif, dan tidak dalam mengerjakan skripsi dengan total keseluruhannya sejumlah 419 Mahasiswa, baik kelas pagi atau kelas sore. Data primer penelitian ini berasal dari jawaban responden atas berbagai pertanyaan yang disampaikan melalui kuesioner terkait dengan Locus of Control, Pengetahuan Keuangan, Sikap Keuangan, dan Perilaku Keuangan. Dengan menggunakan sumber data yaitu kuesioner.

Ada 4 variabel dalam penelitian ini, variabel bebas adalah Pengetahuan Keuangan (X1), Sikap Keuangan (X2), dan Locus Of Contol (X3), sedangkan variabel terikat adalah Perilaku Keuangan (Y). definisi operasional variabel dalam penelitian ini sebagai berikut: Pengetahuan keuangan (X1) adalah pengetahuan yang dimiliki oleh mahasiswa Manajemen UMG tentang keuangan yang nantinya dapat diterapkan dalam pengambilan keputusan keuangan. Indikator Pengetahuan Keuangan (X1) meliputi: Pengelolaan keuangan, Investasi, dan Bank dan Lembaga Keuangan. Sikap keuangan (X2) adalah suatu keadaan dimana mahasiswa Manajemen UMG dapat menilai atau mengutarakan pendapatnya tentang keuangannya. Indikator Sikap keuangan (X2) meliputi: Sisa uang, Anggaran., dan Hemat. Locus of control (X3) adalah pengendalian diri mahasiswa Manajemen UMG yang dapat atau tidak dapat meyakinkan dirinya sendiri. Indikator Locus of control, baik locus of control internal dan locus of control eksternal meliputi:

a. Locus of control internal: (1) percaya diri, (2) merasa puas, dan (3) bekerja keras. b. Locus of control eksternal: (1) tidak percaya diri, (2) tidak inisiatif, dan (3) tidak suka bekerja keras.

Perilaku keuangan (Y) adalah cara mahasiswa Manajemen Universitas Muhammadiyah Gresik dalam mengelola keuangan yang dimiliki. Indikator Perilaku keuangan (Y) meliputi: Mengawasi, Menyediakan dana, dan Menyimpan uang. Pada penelitian ini teknik analisis data yang digunakan adalah pengujian hipotesis dengan menggunakan uji statistik, yaitu melalui analisis regresi linier berganda. Teknik ini untuk mengetahui pengaruh dari masingmasing variabel independen berpengaruh positif atau negatif terhadap variable dependen.

\section{HASIL PENELITIAN}

\section{Gambaran Umum Objek Penelitian}

Dalam penelitian ini yang dijadikan objek penelitian adalah Mahasiswa Prodi Manajemen Universitas Muhammadiyah Gresik. Prodi Manajemen memiliki visi dan misi sebagai berikut:

Visi :

Menjadi Program Studi yang Mandiri dalam menghasilkan sarjana ekonomi unggul dibidang manajemen dan bisnis berdasar pada nilai-nilai keislaman tahun 2022.

Misi :

1. Menyelenggarakan pendidikan manajemen dan bisnis yang berkualitas kepada mahasisa dengan menekankan pada kompetisis, profesionalitas, dan moralitas.

2. Mengembangkan penelitian di bidang manajemen dan bisnis yang berlandaskan kompetensi, kewirausahaan, etika, dan tanggungjawab sosial. 
3. Mengembangkan kemitraan bersama dengan pelaku bisnis beserta masyarakat dalam mengimplementasikan ilmu pengetahuan manajemen dan bisnis sebagai wujud pengabdian kepada masyarakat.

Dalam pengumpulan data, peneliti menggunakan kuesioner/angket yaitu teknik pengumpulan data yang dilakukan dengan cara memberikan beberapa pertanyaan atau pernyataan tertulis kepada Mahasiswa Prodi Manajemen UMG.

\section{Sampel Mahasiswa Manajemen Universitas Muhammadiyah Gresik}

Populasi Mahasiswa Manajemen UMG angkatan 2015-2016 sebanyak 419 mahasiswa. Pemilihan sampel menggunakan metode proportionate stratified random sampling dengan pengambilan sampel menggunakan Tabel Krejcie yang didapatkan sampel sebanyak 191 mahasiswa.

\section{Interpretasi Hasil}

Penelitian ini bertujuan untuk melihat apakah Pengetahuan Keuangan, Sikap Keuangan, dan Locus of Control berpengaruh signifikan terhadap Perilaku Keuangan Mahasiswa Prodi Manajemen UMG. Berdasarkan penelitian dan analisis yang peneliti lakukan dengan menggunakan alat bantu SPSS 19, maka peneliti dapat menginterpretasikan hasil :

Dalam pengujian hipotesis dengan menunjukkan uji $\mathrm{t}$ antara masingmasing variabel independen dan variabel dependen.

\section{Pengetahuan Keuangan (X1) terhadap Perilaku Keuangan (Y)}

Pengetahuan Keuangan (X1) memperoleh $\mathrm{t}$ hitung sebesar $(0,805)$ sedangkan $\mathrm{t}$ tabel sebesar $(1,972)$, sedangkan taraf signifikansi 5\%, dengan demikian hasil penelitian ini menunjukkan bahwa Pengetahuan Keuangan (X1) tidak terbukti berpengaruh signifikan terhadap Perilaku Keuangan (Y). Menurut teori Ersha (2016), menyatakan bahwa pengetahuan keuangan berpengaruh positif terhadap perilaku keuangan. Semakin banyak Pengetahuan Keuangan yang dimiliki oleh mahasiswa Manajemen UMG maka tidak akan berpengaruh secara signifikan terhadap Perilaku Keuangan yang dimiliki. Artinya bahwa seseorang dengan pengetahuan keuangan yang baik akan lebih mempunyai perilaku keuangan yang lebih bertanggung jawab. Namun hanya sedikit atau beberapa responden yang mengetahui tentang ilmu pengetahuan keuangan, hal ini yang menyebabkan beberapa individu kurang baik atau kurang tepat dalam mengelola keuangannya.

\section{Sikap Keuangan (X2) terhadap Perilaku Keuangan (Y)}

Sikap Keuangan (X2) memperoleh t hitung sebesar $(7,292)$ sedangkan $t$ tabel sebesar $(1,972)$, sedangkan taraf signifikansi 5\%, dengan demikian hasil penelitian ini menunjukkan bahwa Sikap Keuangan (X2) berpengaruh signifikan terhadap Perilaku Keuangan (Y), sehingga teori menurut Kurnia (2017) menyatakan bahwa semakin baik sikap keuangan yang dimiliki oleh Mahasiswa Manajemen UMG maka perilaku keuangannya akan semakin baik menunjukkan bahwa sikap keuangan berpengaruh positif terhadap perilaku keuangan terbukti kebenarannya.

Sikap keuangan ini telah diterapkan dengan baik oleh mahasiswa Manajemen UMG. Dalam theory of planned behavior menurut 
Ajen menjelaskan bahwa sikap akan dapat mempengaruhi niat seorang individu. Individu yang telah memiliki sikap keuangan yang baik maka akan memberikan dampak yang positif terhadap perilaku keuangannya. Sikap tersebut telah dimiliki oleh beberapa responden yang juga diikuti dengan perilaku keuangan yang baik pula.

Locus Of Control (X3) terhadap Perilaku Keuangan (Y)

Locus Of Control (X3) memperoleh t hitung sebesar $(3,833)$ sedangkan $t$ tabel sebesar $(1,972)$, sedangkan taraf signifikansi 5\%, dengan demikian hasil penelitian ini menunjukkan bahwa Locus Of Control (X3) berpengaruh signifikan terhadap Perilaku Keuangan (Y). Sehingga teori menurut Kurnia (2017) yang menyatakan bahwa semakin baik Locus Of Control yang Mahasiswa Manajemen UMG miliki, maka akan semakin baik pula Perilaku Keuangannya, menunjukkan bahwa Locus Of Control berpengaruh positif signifikan terhadap perilaku keuangan terbukti kebenarannya. Locus of Control yang dimiliki rata-rata mahasiswa Manajemen Universitas Muhammadiyah Gresik telah diikuti dengan perilaku keuangan yang baik.

\section{KESIMPULAN}

DAN

\section{REKOMENDASI}

\section{Kesimpulan}

Berdasarkan hasil penelitian tentang Pengaruh Pengetahuan Keuangan, Sikap Keuangan, dan Locus Of Control Terhadap Perilaku Keuangan Mahasiswa Prodi Manajemen Universitas Muhammadiyah Gresik, maka dapat disimpulkan:

1. Pengetahuan Keuangan tidak berpengaruh signifikan terhadap Perilaku Keuangan Mahasiswa Prodi Manajemen UMG.
2. Sikap Keuangan berpengaruh positif signifikan terhadap Perilaku Keuangan Mahasiswa Prodi Manajemen UMG.

3. Locus of Control berpengaruh positif signifikan terhadap Perilaku Keuangan Mahasiswa Prodi Manajemen UMG.

\section{Rekomendasi}

Terkait dengan hasil penelitian, pembahasan, dan kesimpulan yang ada dalam penelitian ini, maka peneliti memberikan rekomendasi sebagai berikut:

1. Bagi Mahasiswa Manajemen Universitas Muhammadiyah Gresik

a. Variabel Sikap Keuangan (X2) dan Locus Of Control (X3) berpengaruh signifikan, dengan demikian Mahasiswa Manajemen UMG sebaiknya dapat lebih baik dalam menyikapi dan meningkatkan berbagai hal yang menyangkut dari kedua variabel.

b. Variabel Pengetahuan Keuangan (X1) tidak berpengaruh, maka diperlukan pengetahuan keuangan yang tepat dan lebih banyak agar dapat menghasilkan pemikiran yang cerdas untuk Mahasiswa Manajemen UMG.

2. Bagi peneliti selanjutnya, sebaiknya dapat lebih memperbanyak pada jumlah variabel bebas, sampel, dan menggunakan teknik analisis data yang berbeda agar mendapatkan hasil penelitian yang lebih baik dan sempurna. Hal ini dikarenakan nilai Adjusted R Square sebesar $36 \%$, sehingga terdapat faktor lain yang mempengaruhi perilaku keuangan. Faktor lain tersebut seperti penambahan jumlah 
variabel seperti faktor parental income, lingkungan, kepuasan hidup, stress, yang dapat mempengaruhi perilaku keuangan.

\section{DAFTAR PUSTAKA}

Amanah, Ersha, Dr. Dadan Rahadian, S.T., M.M, Aldila Iradianty, S.E., M.M. 2016. Pengaruh Financial Knowledge, Financial Attitude dan External Locus Of Control Terhadap Personal Financial Management Behavior Pada Mahasiswa S1 Universitas Telkom: Study of Bachelor Degree Student in TelkomUniversity. Jurnal eProceeding of Management. Vol. 3, No. 2, Agustus. ISSN : 2355-9357.

Friedman, Howard S. dan Miriam W. Schustack, 2006. Kepribadian: Teori Klasik dan Riset Modern. Edisi 3. Penerbit Erlangga. Jakarta.

Listiani, Kurnia. 2017. Pengaruh Financial Knowledge, Locus Of Control, dan Financial Attitude Terhadap Financial Management Behavior pada Mahasiswa. Surabaya: STIE Perbanas Surabaya.

M. Nur Ghufron \& Rini Risnawati. (2010). Teori-teori Psikologi. Yogyakarta: Ar-Ruzz Media.
Zahra, Aminatus. 2014. Persepsi Pengaruh Pengetahuan Keuangan, Sikap Keuangan, Sosial Demografi, Terhadap Perilaku Keuangan Dalam Pengambilan Keputusan Investasi Individu: Studi Kasus Pada Mahasiswa Magister Manajemen di universitas Diponegoro. Jurnal Bisnis Strategi. Vol. 23, No. 2, Desember, hal 70-96.

Zahroh, Fatimatus. 2014. Menguji Tingkat Pengetahuan Keuangan, Sikap Keuangan Pribadi, dan Perilaku Keuangan Pribadi Mahasiswa Jurusan Manajemen Fakultas Ekonomika dan Bisnis Semester 3 dan Semester 7. Semarang: Universitas Diponegoro.

Friedman, Howard S. dan Miriam W. Schustack, 2006. Kepribadian: Teori Klasik dan Riset Modern. Edisi 3. Penerbit Erlangga. Jakarta.

Herdjiono, Irine dan Lady Angela Damanik. 2016. Pengaruh Financial Attitude, Financial Knowledge, Parental Income terhadap Financial Management Behavior: Studi Mahasiswa di Merauke. Jurnal Manajemen Teori dan Terapan. Tahun 9 No. 3, Desember. 